Louisiana State University

LSU Digital Commons

Faculty Publications

Department of Biological Sciences

$4-1-2020$

\title{
Advances in the neurophysiology of magnocellular neuroendocrine cells
}

Jeffrey G. Tasker

Tulane University School of Medicine

Masha Prager-Khoutorsky

Université McGill

Ryoichi Teruyama

Louisiana State University

José R. Lemos

University of Massachusetts Medical School

William E. Amstrong

University of Tennessee Health Science Center

Follow this and additional works at: https://digitalcommons.Isu.edu/biosci_pubs

\section{Recommended Citation}

Tasker, J., Prager-Khoutorsky, M., Teruyama, R., Lemos, J., \& Amstrong, W. (2020). Advances in the neurophysiology of magnocellular neuroendocrine cells. Journal of Neuroendocrinology, 32 (4) https://doi.org/10.1111/jne.12826

This Article is brought to you for free and open access by the Department of Biological Sciences at LSU Digital Commons. It has been accepted for inclusion in Faculty Publications by an authorized administrator of LSU Digital Commons. For more information, please contact ir@lsu.edu. 


\title{
Advances in the neurophysiology of magnocellular neuroendocrine cells
}

\author{
Jeffrey G. Tasker ${ }^{1}$ (D) | Masha Prager-Khoutorsky² (D) | Ryoichi Teruyama ${ }^{3}$ | \\ José R. Lemos ${ }^{4}$ (D) | William E. Amstrong ${ }^{5}$ (i)
}

${ }^{1}$ Department of Cell and Molecular Biology and Tulane Brain Institute, Tulane University, New Orleans, LA, USA

${ }^{2}$ Department of Physiology, McGill University, Montreal, QC, Canada

${ }^{3}$ Department of Biological Sciences, Louisiana State University, Baton Rouge, LA, USA

${ }^{4}$ Department of Microbiology and Physiological Systems \& Program in Neuroscience, University of Massachusetts Medical School, Worcester, MA, USA

${ }^{5}$ Department of Anatomy and Neurobiology and Neuroscience Institute, University of Tennessee Health Science Center, Memphis, TN, USA

\section{Correspondence}

Jeffrey Tasker, Tulane University, Cell and Molecular Biology Dept, 2000 Percival Stern Hall, New Orleans, LA 70118, USA.

Email: tasker@tulane.edu

William Armstrong, University of Tennessee Health Science Center, Anatomy and Neurobiology Department and Neuroscience Institute, 855 Monroe Ave, Memphis, TN 38163, USA.

Email:warmstro@uthsc.edu

Funding information

Heart \& Stroke Foundation of Canada, Grant/Award Number: National New Investigator Award; Canadian Institutes of Health Research, Grant/Award Number: PJT-153009; NIH, Grant/Award Number: P20GM103642, R01HD072056, R01HL115208, R01NS042081, R01NS29470 and R21HL093728

\begin{abstract}
Hypothalamic magnocellular neuroendocrine cells have unique electrical properties and a remarkable capacity for morphological and synaptic plasticity. Their large somatic size, their relatively uniform and dense clustering in the supraoptic and paraventricular nuclei, and their large axon terminals in the neurohypophysis make them an attractive target for direct electrophysiological interrogation. Here, we provide a brief review of significant recent findings in the neuroplasticity and neurophysiological properties of these neurones that were presented at the symposium "Electrophysiology of Magnocellular Neurons" during the 13th World Congress on Neurohypophysial Hormones in Ein Gedi, Israel in April 2019. Magnocellular vasopressin (VP) neurones respond directly to hypertonic stimulation with membrane depolarisation, which is triggered by cell shrinkage-induced opening of an $\mathrm{N}$-terminaltruncated variant of transient receptor potential vanilloid type-1 (TRPV1) channels. New findings indicate that this mechanotransduction depends on actin and microtubule cytoskeletal networks, and that direct coupling of the TRPV1 channels to microtubules is responsible for mechanical gating of the channels. Vasopressin neurones also respond to osmostimulation by activation of epithelial $\mathrm{Na}^{+}$channels (ENaC). It was shown recently that changes in $\mathrm{ENaC}$ activity modulate magnocellular neurone basal firing by generating tonic changes in membrane potential. Both oxytocin and VP neurones also undergo robust excitatory synapse plasticity during chronic osmotic stimulation. Recent findings indicate that new glutamate synapses induced during chronic salt loading express highly labile $\mathrm{Ca}^{2+}$-permeable GluA1 receptors requiring continuous dendritic protein synthesis for synapse maintenance. Finally, recordings from the uniquely tractable neurohypophysial terminals recently revealed an unexpected property of activity-dependent neuropeptide release. A significant fraction of the voltage-dependent neurohypophysial neurosecretion was found to be independent of $\mathrm{Ca}^{2+}$ influx through voltage-gated $\mathrm{Ca}^{2+}$ channels. Together, these findings provide a snapshot of significant new advances in the electrophysiological signalling mechanisms and neuroplasticity of the hypothalamic-neurohypophysial system, a system that continues to make important contributions to the field of neurophysiology.
\end{abstract}




\section{1 | INTRODUCTION}

The classically defined hypothalamic-neurohypophysial system consists of magnocellular vasopressin (VP)- and oxytocin (OT)-secreting neurones and their axonal projections to the neurohypophysis, the electrical activities of which are tightly coupled to the pattern and amount of neurohypophysial hormone release. ${ }^{1}$ The system's well described physiological functions with respect to regulating blood pressure, water and salt balance, and parturition/lactation, combined with the ability to precisely identify neurone types in vivo and in vitro both anatomically and electrophysiologically, have made it a model system for understanding neuropeptide-secreting neurones. Here, we describe recent significant advances in the neurophysiology of the hypothalamic-neurohypophysial system that were presented at the 2019 annual World Congress on Neurohypophysial Hormones in Ein Gedi, Israel.

A unique property of the magnocellular OT and VP neurones is their intrinsic osmosensitivity, ${ }^{2-4}$ a property that involves dynamic changes in cell size and activation of a non-selective cation channel formed by an $\mathrm{N}$-terminal-truncated variant of the transient receptor potential vanilloid type-1 (TRPV1) channel, which serves as a mechanoreceptor. $^{5-7}$ Recent work described here by Prager-Khoutorsky reveals that these changes are dependent on complex plasticity in the cytoskeletal machinery of actin filaments and microtubules, the latter of which are tethered directly to the $\triangle \mathrm{N}$-TRPV1 channels. Together these elements respond to changes in osmotic pressure, eg, hypertonicity, which causes cell shrinkage leading to depolarisation of the magnocellular neurones and an increase in action potential activity and hormone release.

A striking feature of the hypothalamic-neurohypophysial system is the remarkable degree of morphological and physiological plasticity exhibited under conditions of sustained hormone demand, such as during lactation and chronic dehydration, presumably to adapt its properties to afford efficient secretion as neurosecretory stores become progressively depleted. These adaptations involve dynamic morphological changes in neuronal-glial relationships in the hypothalamic magnocellular nuclei and coincident synaptic rearrangements. ${ }^{8-11}$ Early studies first demonstrated increased synaptic contacts as well as somatic and dendritic membrane close appositions coupled to the retraction of glial processes during chronic dehydration and lactation, which were followed more recently by studies of plasticity in synaptic and membrane properties. ${ }^{12-14}$ Plasticity during enhanced demand for hormone can take various forms, including changes in presynaptic facilitation during repetitive activity, ${ }^{15,16}$ modification of transmitter receptor channels, ${ }^{17,18}$ up-regulation of intrinsic currents, ${ }^{19-22}$ and dynamic regulation of $\mathrm{Cl}^{-}$buffering to shape inhibitory synaptic responses. ${ }^{9,23,24}$ As highlighted here by Teruyama, Tasker and Prager-Khoutorsky, chronic salt intake is a reliable means of osmotically stressing the system and inducing these adaptive changes; in this case, changes in epithelial
$\mathrm{Na}^{+}$channels ( $\mathrm{ENaCs}$ ) that contribute to the resting membrane potential specifically in VP neurones, AMPA receptors that provide the excitatory drive to OT and VP neurones and contribute to synaptic plasticity, and microtubules that are involved in the regulation of autonomous osmosensitivity of VP neurones. Thus, plasticity in the hypothalamic-neurohypophysial system in response to chronic challenges is multi-dimensional, from morphological restructuring to changes in ion channel and neurotransmitter receptor expression and function, and serves to shape the electrical activity needed to sustain hormone release in the face of changing physiological demand.

Unlike the great majority of mammalian neurones, the axon terminals of OT and VP neurones are large and, therefore, amenable to electrophysiological recording, which allows the high-resolution characterisation of $\mathrm{Ca}^{2+}$-secretion coupling. ${ }^{25-28}$ Recordings from axon terminals in the neurohypophysis have provided detailed insight, for example, into the complex $\mathrm{Ca}^{2+}$ buffering that occurs in axons ${ }^{29}$ and the second messenger modulation of hormone secretion. ${ }^{22}$ Recent work described here by Lemos suggests an unexpectedly prominent role of $\mathrm{Ca}^{2+}$ release from ryanodine-sensitive internal stores in the release of OT and VP. Thus, true to form, the hypothalamic-neurohypophysial system, because of its tractability to experimental study, continues to drive new directions of neurophysiological discovery.

\section{1 | The role of cytoskeletal networks in the osmosensitivity of vasopressin neurones}

Magnocellular neurosecretory cells are intrinsically osmosensitive. The firing activity of isolated magnocellular neurones is increased by hypertonicity and inhibited by hypotonicity in the absence of synaptic inputs and the surrounding glial cells. ${ }^{2,30-32}$ This modulation of neuronal activity in response to changes in extracellular fluid osmolality is associated with changes in cell volume. A hypertonic extracellular environment causes water to flow out of the cell to balance the elevated concentration of solutes in the extracellular fluid, resulting in cell shrinkage, which in turn leads to cell excitation and an increase in the firing rate of magnocellular neurones. A hypotonic environment causes water to flow into the cell, inducing cell swelling and leading to a decrease in the firing rate of these neurones. ${ }^{30,32,33}$ This autonomous osmolality-induced modulation of neuronal activity is a mechanical process linked to cell shrinking and swelling because it can be achieved without alterations in solute concentration or ionic strength by changing cell volume via application of negative or positive pressure through a whole-cell patch pipette. ${ }^{33-35}$ By contrast to other cell types that strive to restore their volume in response to changes in the extracellular osmolality, ${ }^{36,37}$ magnocellular neurones exhibit sustained osmolality-induced changes in cell 
volume, and these changes are inversely proportional to the extracellular fluid osmolality. ${ }^{33,38}$ This feature is crucial because the activity of magnocellular neurones should be modulated for as long as blood plasma osmolality is above or below the set point, to ensure an appropriate secretion of VP and OT to restore fluid balance.

\subsection{1 | The role of TRPV1 channels}

The modulation of magnocellular neurone activity by osmolality or mechanical stimulation is mediated by the activation/inhibition of a non-selective cation current that causes cell depolarisation/hyperpolarisation, leading to an increase/decrease in the action potential firing rate. As briefly described above, recent studies demonstrated that the TRPV1 channel mediates this effect. ${ }^{6,7}$ Supraoptic nucleus (SON) neurones express a truncated $\mathrm{N}$-terminal variant of the TRPV1 channel ( $\triangle \mathrm{N}$-TRPV1), ${ }^{7}$ and magnocellular neurones isolated from TRPV1 knockout mice lack autonomous responses to hypertonicity or suction-induced shrinking. ${ }^{6}$ Moreover, TRPV1 knockout mice display chronically elevated blood osmolality under basal conditions, as well as attenuated VP release in response to acute hyperosmotic stimulation in vivo. ${ }^{6}$ These findings suggest that the $\triangle \mathrm{N}$-TRPV1 is a mechanosensitive ion channel that can be activated by a decrease in cell volume (triggered by hypertonicity or suction) to mediate osmotically-induced responses in the magnocellular neurosecretory cells. ${ }^{5,7}$

\subsection{2 $\mid$ The role of actin}

Because the autonomous responses of magnocellular neurones to hypertonicity are mediated by the mechanical activation of $\Delta \mathrm{N}$ TRPV1, the intracellular cytoskeleton appears to be a key element that can convert forces generated during cell volume changes into the activation of these channels. Indeed, studies have shown that magnocellular neurosecretory cells feature a thin layer of actin filaments beneath the plasma membrane (Figure 1A). Whole-cell patch-clamp recordings from isolated magnocellular neurones demonstrated that hypertonicity-induced depolarisation and increases in the firing rate of these neurones are blocked by cytochalasin $D$, a compound that depolymerises actin filaments. By contrast, stabilisation of actin filaments with jasplakinolide, a drug that promotes actin polymerisation, potentiates the activation of magnocellular neurones in response to hypertonicity or suction-induced shrinking. Importantly, pharmacological modification of the actin cytoskeleton in magnocellular neurones does not affect the cell shrinking in response to osmotic or mechanical stimuli, although it changes the coupling between the cell volume and neuronal excitation. ${ }^{34,39}$ Notably, another study demonstrated that angiotensin II potentiates the autonomous responses of SON neurones to hypertonicity or suction-induced shrinking. This increase in the intrinsic osmosensitivity of magnocellular neurones is mediated by phospholipase $\mathrm{C}$ and a $\mathrm{Ca}^{2+-}$ dependent form of protein kinase $\mathrm{C}$, leading to an increase in cortical actin density in these neurones. ${ }^{39,40}$ These findings indicate that the actin cytoskeleton plays an important role in the autonomous osmosensitivity of magnocellular neurones, and that the sensitivity of osmotic activation can be bi-directionally modulated by changing the density of the actin layer. ${ }^{34,39,40}$

Despite these important findings, the molecular mechanism by which the actin cytoskeleton regulates the osmotic activation of $\Delta \mathrm{N}$-TRPV1 in magnocellular neurones remains unknown. It is plausible that the subcortical actin layer creates a scaffold underneath the plasma membrane that provides mechanical support during shrinkage and/or transmits forces essential for the mechanical activation of the transduction channels. ${ }^{41}$ However, the direct evidence supporting the notion that actin is physically associated with $\Delta \mathrm{N}$ TRPV1 channels or mediates their mechanical gating is currently missing. ${ }^{42,43}$ Further work is required to examine the organisation of the actin cytoskeleton under basal conditions and in response to osmotic stimuli, aiming to determine how changes in the cell volume affect the organisation of cortical actin to modulate the activation of $\Delta \mathrm{N}-\mathrm{TRPV} 1$ channels.

\subsection{3 $\mid$ The role of microtubules}

In addition to the actin cytoskeleton, a recent study by PragerKhoutorsky et $\mathrm{al}^{44}$ showed that microtubules also play an essential role in the osmotic and mechanical activation of magnocellular neurosecretory cells. By contrast to actin filaments, which form a thin subcortical layer in these neurones, microtubules create a highly complex three-dimensional network of filaments that occupy the entire cytoplasm of neuronal somata (Figure 1B). Super-resolution imaging of microtubules in situ in different areas of the rodent brain revealed that magnocellular VP neurones from the SON and paraventricular nucleus (PVN) feature a unique microtubule structure that is strikingly different from the rectilinear microtubules commonly observed in other types of neurones, ${ }^{44-46}$ and from the typical pattern of centrosome-divergent microtubules found in somatic cells. ${ }^{47}$ Thus, this interwoven microtubule network appears to be a unique feature of the magnocellular neurosecretory cells. This structure is comprised of a remarkably dense scaffold of filaments that extend from the nucleus to the plasma membrane, with the microtubule tips positioned very close to the cell surface and contacting the plasma membrane at multiple points. ${ }^{44}$ Furthermore, it was demonstrated that microtubules interact with $\triangle \mathrm{N}$-TRPV1 channels on the plasma membrane of magnocellular neurones via two highly-conserved $\beta$-tubulin binding domains on the $\mathrm{C}$-terminus of the channel, ${ }^{42,48}$ and such interactions are essential for the autonomous cell response to osmolality. ${ }^{44}$ Disrupting microtubules with nocodazole decreases the number of interactions between microtubules and $\triangle \mathrm{N}$-TRPV1 at the cell surface and inhibits the activation of the neurones in response to hypertonicity or suction-induced shrinking. Stabilisation of microtubules with taxol elevates microtubule density and increases the number of microtubule-to- $\Delta \mathrm{N}$ TRPV1 interactions and amplifies the activation of magnocellular 
(A) Actin \& Vasopressin

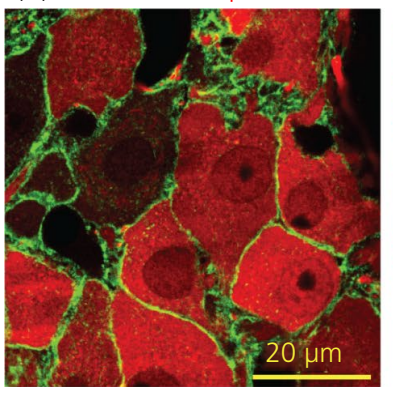

(B)

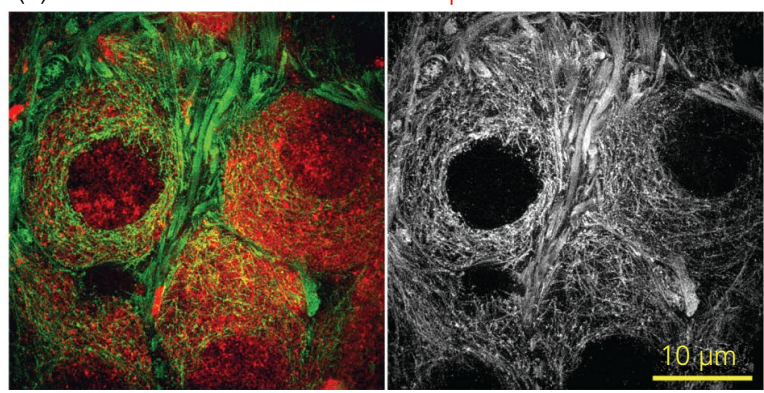

FIGURE 1 Cytoskeletal networks in magnocellular vasopressin (VP) neurones. (A) Immunostaining for actin (green) and VP (red) in a supraoptic nucleus (SON) section of the adult rat brain analysed by confocal imaging. (B) Immunostaining for $\alpha$-tubulin (green or white) and VP (red) in a SON section of adult rat brain analysed by super-resolution structured illumination microscopy. Note that magnocellular VP neurones feature a submembrane cortical actin layer and an interweaved cytoplasmic microtubule scaffold. Microtubules extend all the way to the plasma membrane of the neurones, where they interact with the transduction channels $(\triangle \mathrm{N}-\mathrm{TRPV} 1)^{41}$
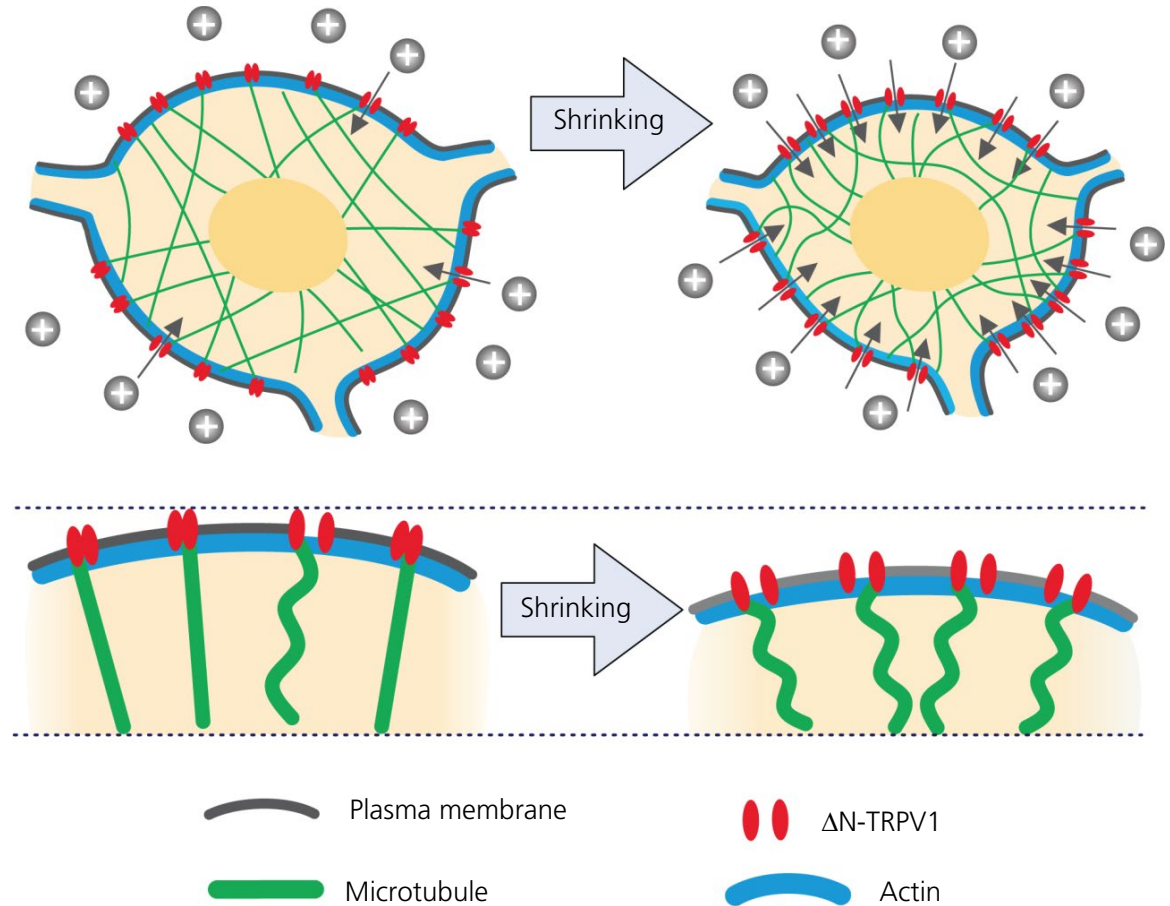

ON-TRPV1

Actin
FIGURE 2 Model illustrating the role of actin and microtubules in the mechanical activation of the transduction channels in response to hypertonicity-mediated cell shrinking. At rest, $\triangle \mathrm{N}$-TRPV1 channels are attached to microtubules, although only few are activated because of a lack of sufficient pushing force. As a result of hypertonicity-induced cell shrinkage, the plasma membrane shifts inward, increasing the proportion of microtubules that push onto and activate $\triangle \mathrm{N}$-TRPV1 channels. Cortical actin does not directly interact with the transduction channel. In response to cell shrinkage, this elastic layer transmits changes in cell volume into the adequate movement of the plasma membrane, resulting in microtubule compression and push activation of the transduction channels, leading to cell excitation neurones in response to shrinking. Moreover, specific disruption of these interactions by infusing isolated SON neurones with synthetic peptides mimicking the C-terminus binding domains of $\Delta \mathrm{N}$ TRPV1 blocks the shrinking-induced depolarisation and increase in the firing rate of the neurones. ${ }^{44}$ These findings suggest that the interaction between the microtubule network and $\triangle \mathrm{N}$-TRPV1 channels is necessary for the autonomous activation of magnocellular neurones during cell shrinkage, and that the sensitivity of this process can be bi-directionally modulated by changing the stability of the microtubule network and the density of its interactions with the transduction channels. ${ }^{44}$

These studies propose a new model (Figure 2) to explain the autonomous mechanism underlying the activation of magnocellular neurones in response to hypertonicity-induced shrinking. This "push activation" model suggests that the activation of the transduction channel ( $\triangle \mathrm{N}$-TRPV1) during cell shrinkage may result from a pushing force generated by microtubules attached to $\Delta \mathrm{N}$-TRPV1 channels as result of their compression during cell shrinking. Single-channel cell-attached recordings demonstrate that a brief positive pressure pulse applied to the membrane underneath the patch pipette is sufficient to rapidly activate channels in this membrane fragment and are consistent with this model, supporting the notion that $\triangle \mathrm{N}-\mathrm{TRPV} 1$ is activated directly by the application of a pushing force through the attached microtubule filament. ${ }^{35,41,44}$

Additional testing of this model is required to determine how hypertonicity-induced cell shrinkage modifies the microtubule network leading to the activation of $\triangle \mathrm{N}$-TRPV1 channels and to examine how hypotonicity-induced cell swelling affects microtubule organisation and its interaction with the transduction channels leading to inhibition of channel activity and decreased neuronal activation. 
Thus, recent studies have revealed that magnocellular neurosecretory cells are intrinsically osmosensitive and generate autonomous responses to changes in the extracellular fluid osmolality. This autonomous osmosensitivity is mediated by mechanical activation of $\triangle N$-TRPV1 channels in response to changes in cell volume. Two major cytoskeletal elements, actin filaments and microtubules, are essential components that mediate intrinsic responses to changes in osmolality in magnocellular neurones, and modulation of the stability of these cytoskeletal networks causes proportional changes in the sensitivity of neuronal activation. The mechanism by which actin regulates $\triangle \mathrm{N}$-TRPV1 activation remains unclear because previous studies suggest that actin does not bind directly to TRPV1 channels, and thus the effect of the actin network on the activity of the transduction channel is likely indirect. Conversely, microtubules directly bind to the $\mathrm{C}$-terminus of the $\triangle N$-TRPV1, and this interaction appears to be critical for the osmotic activation of the channel, presumably by providing a pushing force that causes the mechanical gating of the channel (Figure 2). Notably, both actin filaments and microtubules are essential for the osmotic activation of the neurones, as disrupting their stability blocks the hypertonicity-mediated autonomous response. Moreover, stabilising each of these cytoskeletal networks amplifies the activation of neurones by changes in osmolality. Interestingly, Hicks et $\mathrm{al}^{46}$ demonstrated recently that the density of microtubules in magnocellular VP neurones increases in response to salt loading. The organisation of microtubules in other brain areas remains unchanged following salt loading, and only microtubule cytoskeleton in magnocellular SON and PVN neurones is modulated by this condition. ${ }^{46}$ Because an enhancement of microtubule density is sufficient to elevate the autonomous osmosensitivity of VP magnocellular neurones, ${ }^{44}$ the increase in microtubule density following salt loading can facilitate the activation of magnocellular VP neurones, contributing to excessive VP release and elevated blood pressure in this condition.

\section{2 | Epithelial $\mathrm{Na}^{+}$channels in magnocellular VP neurones}

The epithelial $\mathrm{Na}^{+}$channel $(\mathrm{ENaC})$ is an amiloride-sensitive and nonvoltage-dependent, sodium-selective ion channel. A functional $\mathrm{ENaC}$ is composed of three homologous subunits, $\alpha, \beta$ and $\gamma$, which are
FIGURE 3 Epithelial $\mathrm{Na}^{+}$channel $(\mathrm{ENaC})$ expression in vasopressin (VP) neurones. (A) The three $\mathrm{ENaC}$ subunits, $\alpha \mathrm{ENaC}, \beta \mathrm{ENaC}$ and $\gamma \mathrm{ENaC}$, are expressed in VP neurones but not oxytocin (OT) neurones of the supraoptic nucleus (SON).

(B) Blocking $\mathrm{ENaC}$ with bath application of benzamil caused a reversible hyperpolarisation and cessation of action potentials in a spontaneously firing VP neurone recorded in a hypothalamic slice. (C) Phasic bursting activity in a VP neurone (upper) and a frequency histogram (lower) during benzamil application and washout. Benzamil did not change the phasic bursting pattern, including intra-burst spiking frequency, interspike interval or burst duration. Arrows: slow depolarisations leading to phasic bursting in the presence and absence of benzamil. VP-NP, vasopressinassociated neurophysin; OT-NP, oxytocinassociated neurophysin. Modified with permission from Teruyama et al $^{76}$
(A)

VP-NP
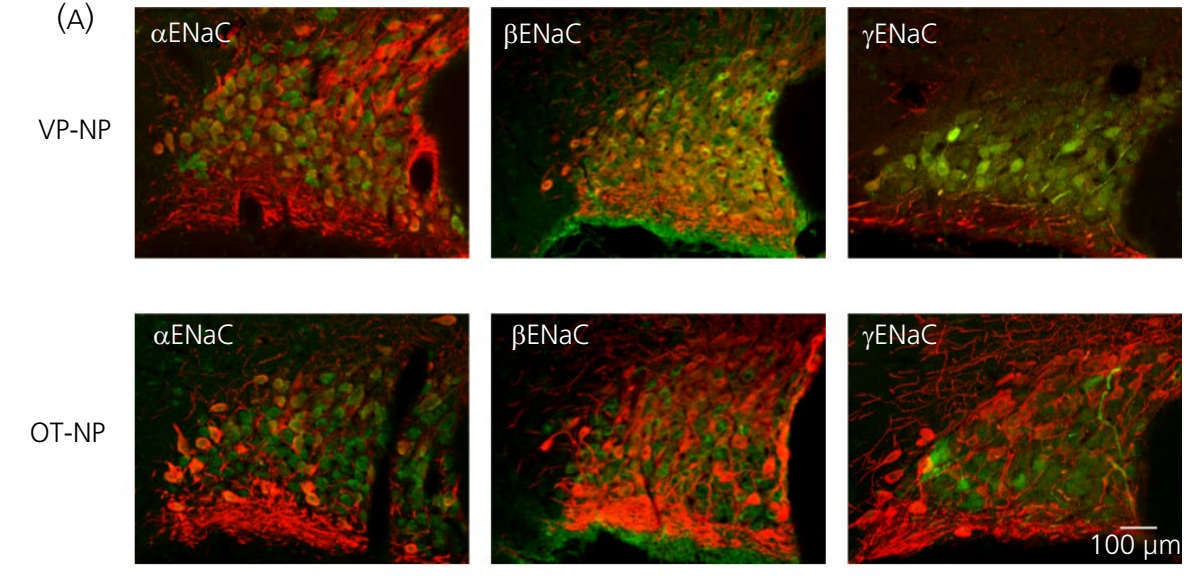

(B)

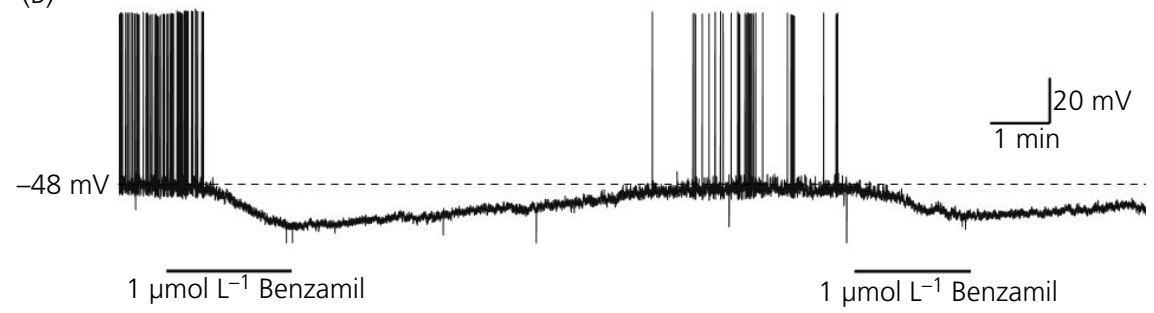

(c)
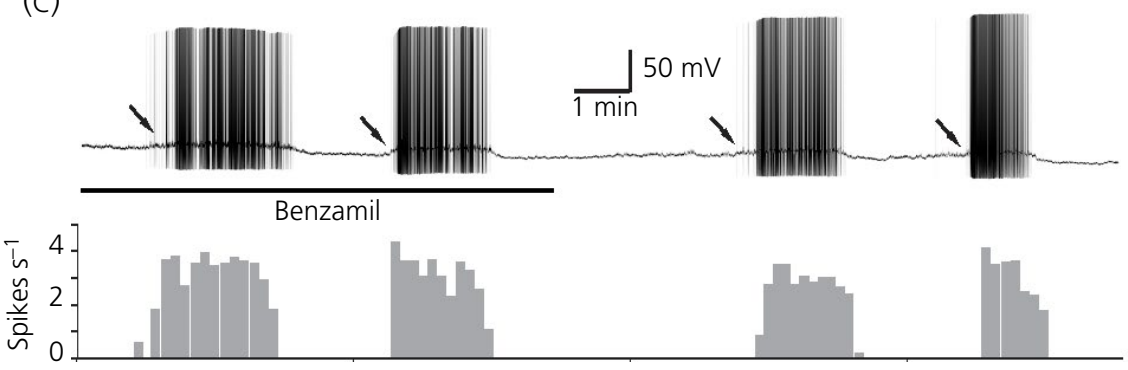
assembled into a heteromultimeric complex. ${ }^{49-51}$ Although the stoichiometry of $\mathrm{ENaC}$ remains uncertain, the total number of subunits varying from four to nine, ${ }^{50-55}$ and it is generally agreed that each of the three $\mathrm{ENaC}$ subunits contributes to the formation of the functional channel complex. ${ }^{50,56} \mathrm{ENaCs}$ are widely expressed in aldosteronesensitive epithelial cells, where aldosterone induces the expression of $\mathrm{ENaC}$ subunits via activation of the mineralocorticoid receptor (MR). In the context of blood pressure regulation, $\mathrm{ENaCs}$ located in the distal nephron of the kidney are known to modulate $\mathrm{Na}^{+}$reabsorption, thereby regulating blood pressure and extracellular fluid volume. ${ }^{57,58}$ In humans, most of the known genetic causes of hypertension are a result of defects either in $\mathrm{ENaC}$ itself or its regulation, which result in abnormal increases in renal $\mathrm{Na}^{+}$reabsorption. ${ }^{59-63}$

Amiloride is a potent $\mathrm{ENaC}$ channel blocker, and amiloride-sensitive cells in the brain are also implicated in the regulation of blood pressure. In particular, dysregulation of amiloride-sensitive cells contributes to salt-sensitive hypertension. Intracerebroventricular infusion of amiloride, or its analogue, benzamil, prevents (i) salt-induced hypertension in Dahl salt-sensitive rats ${ }^{64,65}$; (ii) hypertension induced by i.c.v. infusion of aldosterone in normal rats ${ }^{66}$; and (iii) hypertension induced by the combination of angiotensin II and a high-salt diet. ${ }^{67-72}$ These effects likely were mediated by ENaCs in the brain because the doses were lower than those having a physiological effect in the general circulation. Despite these findings, the mechanism underlying how $\mathrm{ENaCs}$ in the brain are involved in the development of hypertension still remains known.

All three $\mathrm{ENaC}$ subunits have been found in epithelial cells of the choroid plexus ${ }^{73,74}$ and in magnocellular neurones of the SON and PVN. ${ }^{75}$ In the SON and PVN, all three ENaC subunits were found specifically in VP but not in OT neurones (Figure 3A). ${ }^{76} \mathrm{ENaCs}$ in the epithelia of the choroid plexus regulate the $\left[\mathrm{Na}^{+}\right]$in the cerebrospinal fluid, ${ }^{73,74}$ whereas the regulation and function of ENaCs in VP neurones is poorly understood. Considering the role of VP in both neuroendocrine and autonomic responses, the presence of $\mathrm{ENaCs}$ in VP neurones suggests their involvement in the development of salt-sensitive hypertension. Here, we discuss the functional significance and regulation of ENaCs in VP neurones.

\subsection{1 | ENaCs mediate a steady-state $\mathrm{Na}^{+}$leak current that affects the resting membrane potential of VP neurones}

The persistent $\mathrm{K}^{+}$current produces a significant leak current in VP neurones that is active when the neurones are at rest. ${ }^{77}$ However, the resting membrane potential of VP neurones is approximately $-65 \mathrm{mV},{ }^{78}$ which is significantly more depolarised than the $\mathrm{K}^{+}$reversal potential of $-96 \mathrm{mV},{ }^{79}$ suggesting the presence of a $\mathrm{Na}^{+}$leak current. Teruyama et $\mathrm{al}^{76}$ recently demonstrated that $\mathrm{ENaC}$ mediates a $\mathrm{Na}^{+}$leak current that is active near the resting potential and that significantly affects the membrane potential. Thus, application of the ENaC inhibitor benzamil caused a hyperpolarisation and cessation of firing in VP neurones, whereas activation of
$\mathrm{ENaC}$ (eg, via washout of benzamil) caused a depolarisation and increased the frequency of action potentials (Figure 3B). These results, therefore, suggest that ENaCs contribute to the VP neurone resting membrane potential.

\subsection{2 | ENaC activity does not directly affect phasic bursting activity in VP neurones}

Vasopressin neurones respond to hyperosmolality, hypovolemia and hypotension by increasing their firing rate and adopting a phasic bursting pattern of spiking activity, comprising alternating periods of spiking $(7-15 \mathrm{~Hz})$ and silence, with each phase lasting tens of seconds. The release of VP is maximised by stimulation patterns mimicking phasic bursting. ${ }^{80,81}$ Although phasic bursting in vivo is initiated typically by synaptic inputs, ${ }^{82}$ this pattern can be observed in in vitro brain slices in the absence of synaptic inputs. ${ }^{83}$ Therefore, the intrinsic membrane properties that affect the phasic bursting that determines the release of VP are of great interest. Sharma et $\mathrm{al}^{84}$ found that phasic bursting was observed in the presence of benzamil and synaptic blockers, indicating that $\mathrm{ENaC}$ activity does not affect the initiation, maintenance or termination of phasic bursting (Figure $3 \mathrm{C}$ ). Moreover, the application of benzamil did not affect the mean intra-burst frequency, burst duration or interspike interval variability of phasic bursts. The repetitive firing of VP neurones is critically regulated by intrinsic membrane properties, such as the $\mathrm{Ca}^{2+}$-dependent depolarising afterpotential and afterhyperpolarisation. ${ }^{85}$ By modulating the resting membrane potential, $\mathrm{ENaC}$ plays only a minor role in the regulation of the firing activity of VP neurones in the absence of synaptic inputs, although these channels would nevertheless affect how synaptic potentials summate to cross the threshold for spike generation that leads to phasic bursting. This possibility must be examined in the future using an in vivo approach.

\subsection{3 | Dietary salt intake affects the expression and activity of ENaCs}

The expression and activity of ENaCs in epithelial tissues are known to be affected by dietary salt intake, ${ }^{58}$ because the release of aldosterone, a known regulator of $\mathrm{ENaC}$, is influenced by dietary salt. For example, deficiency in dietary salt intake increases circulating aldosterone, which promotes the abundance and activity of $\mathrm{ENaCs}$ in the renal collecting ducts to increase $\mathrm{Na}^{+}$retention. ${ }^{86}$ Sharma et al ${ }^{84}$ investigated whether dietary salt intake also affects ENaC activity in VP neurones. Groups of animals were fed a salt-deficient, control or high-salt diet for 7 days and changes in the relative amounts of $\mathrm{ENaC}$ subunit mRNAs were assessed. The salt-deficient diet, known to increase the circulating level of aldosterone,${ }^{87}$ caused a significant increase in $\alpha E N a C$ mRNA in the kidney but not in the SON. Intriguingly, high dietary salt intake, which decreases the circulating level of aldosterone, ${ }^{88,89}$ caused 
$\mathrm{NaCl}$-deficient

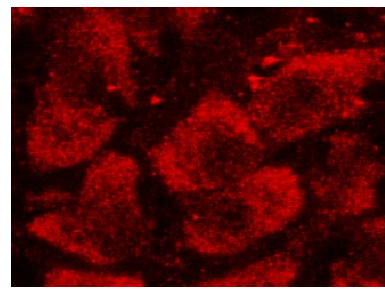

Control

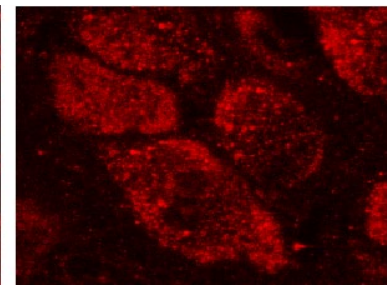

High-NaCl

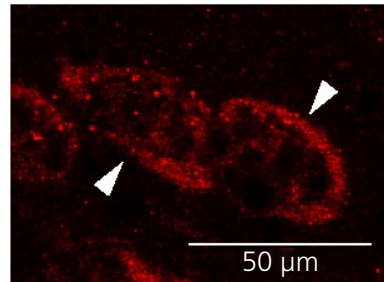

FIGURE 4 Dietary salt regulation of epithelial $\mathrm{Na}^{+}$channel (ENaC) expression in vasopressin (VP) neurones. A low-salt diet ( $\mathrm{NaCl}$ deficient) caused an increase in ENaC expression in VP neurones compared to the control diet, and a high-salt diet caused a decrease in $\mathrm{ENaC}$, which was localised largely at the VP neurone plasma membrane (High- $\mathrm{NaCl}$ ). Modified with permission from Sharma et al ${ }^{84}$

an increase in the expression of $\beta$ and $\gamma \mathrm{ENaC}$ subunits in the SON but not in the kidney. Moreover, translocation of $\alpha \mathrm{ENaC}$ immunoreactivity towards the plasma membrane was observed in VP neurones from animals on a high-salt diet but not from animals fed a salt-deficient or control diet (Figure 4). This is in stark contrast to the regulation of $\mathrm{ENaC}$ in the kidney, where $\mathrm{Na}^{+}$deficiency in the diet or high circulating levels of aldosterone induce a selective up-regulation of $\alpha \mathrm{ENaC}$ and redistribution of $\mathrm{ENaC}$ labelling to the apical membrane of the collecting duct principal cells. ${ }^{86,87}$ These findings suggest that $\mathrm{ENaC}$ subunits in VP neurones are regulated independently from $\mathrm{ENaC}$ subunits in the kidney. Interestingly, aldosterone also induces the expression of $\gamma \mathrm{ENaC}$ via $\mathrm{MR}$ in VP neurones in in vitro slice preparations, ${ }^{90}$ suggesting that the expression of $\mathrm{ENaC}$ in VP neurones may be regulated by aldosterone synthesised in the hypothalamus, independent of aldosterone produced by the adrenal gland. ${ }^{91-93}$

Sharma et $\mathrm{al}^{84}$ went on to examine the effect of the enhanced expression and subcellular translocation of $\mathrm{ENaC}$ in response to high dietary salt intake on the electrophysiological properties of VP neurones. VP neurones from animals fed a high-salt diet exhibited a significantly greater $\mathrm{ENaC}$ current compared to controls. Teruyama and colleagues also confirmed that the enhanced $\mathrm{ENaC}$ current contributed to the more depolarised resting membrane potential observed in VP neurones in the high-salt diet group. ${ }^{84}$ Spontaneous firing can be observed within a relatively narrow range of membrane potentials (-48 $\mathrm{mV}$ to $-55 \mathrm{mV}$ ) in VP neurones recorded in vitro. ${ }^{21}$ The more depolarised potentials result in continuous or phasic burst firing, whereas a slightly hyperpolarised potential results in a slow irregular firing pattern or no firing at all. ${ }^{94}$ This suggests that small alterations in the resting potential are a powerful means to modulate the firing patterns that ultimately control hormone secretion according to physiological demands.

Thus, VP neurones express all three $\mathrm{ENaC}$ subunits to form functional $\mathrm{ENaCs}$ that mediate a steady-state $\mathrm{Na}^{+}$leak current that influences the resting membrane potential. High dietary salt intake causes up-regulation of $\mathrm{ENaC}$ expression and increased activity in VP neurones. The enhanced $\mathrm{ENaC}$ current is responsible for the more depolarised resting membrane potential observed in VP neurones under conditions of high dietary salt intake, and may influence how synaptic potentials reach the threshold for action potential generation. Because the release of VP from the neurohypophysis is controlled by the frequency and pattern of firing in VP neurones and $\mathrm{ENaC}$ is regulated by salt intake, $\mathrm{ENaC}$ may play an important role in the increase in VP secretion known to occur during high-salt consumption.

\section{3 | AMPA receptor plasticity induced in magnocellular neurones by salt loading}

As introduced briefly above, OT and VP neurones undergo a structural and functional plasticity in response to chronic physiological stimulation, such as salt loading, which affects both glutamatergic and GABAergic synaptic circuits. ${ }^{95}$ This plasticity is characterised by a reorganisation of the SON and PVN that includes somatic hypertrophy and withdrawal of astrocytic processes from around neuronal membranes. ${ }^{96,97}$ The glial retraction and resulting uncovering of magnocellular dendritic and somatic membrane triggers synaptogenesis of both GABA and glutamate synapses, ${ }^{98}$ alters ionic buffering, and modulates synaptic signalling in the magnocellular neurones. ${ }^{99}$ Salt loading by high-salt consumption is a strong inductive stimulus of magnocellular plasticity that leads to a hypertensive phenotype in rats. ${ }^{99}$

\subsection{1 | Salt loading-induced GABA synapse plasticity}

Salt loading leads to an increase in GABAergic synaptic contacts with the magnocellular neurones, ${ }^{100}$ as well as changes in functional GABAergic synaptic inputs. ${ }^{101}$ Additionally, the driving force on GABA inhibitory synaptic currents has also been reported to change significantly with salt loading, rendering GABA currents less inhibitory and even excitatory. ${ }^{99,102}$ This is mediated by alterations in the transmembrane transport of $\mathrm{Cl}^{-}$, the main ion that flows through $\mathrm{GABA}_{A}$ receptor channels, which is caused by salt loading-induced changes in the activity of $\mathrm{Cl}^{-}$co-transporters in magnocellular neurones. ${ }^{99,102,103}$ The $\mathrm{K}^{+}-\mathrm{Cl}^{-}$co-transporter 2 (KCC2), for example, is highly sensitive to fluid osmolality, as well as to the reproductive state, ${ }^{104}$ and is largely responsible for establishing the transmembrane $\mathrm{Cl}^{-}$gradient and therefore determining $\mathrm{Cl}^{-}$flow across the membrane. Indeed, the baseline KCC2 expression in VP neurones is low compared to that in 
OT neurones, causing the $\mathrm{Cl}^{-}$equilibrium potential, and therefore the GABA reversal potential, to be shifted in VP neurones under certain conditions without a significant osmotic challenge. ${ }^{105-107}$

\subsection{2 | Salt loading-induced glutamate synapse plasticity}

In addition to the GABA synapse plasticity, glutamate synapses on magnocellular neurones also undergo a significant proliferation with chronic salt loading ${ }^{14,100,101,108}$; however, it was only recently shown that the salt loading-induced plasticity in glutamate synapses includes coincident changes in glutamate receptor expression, subunit composition and signalling properties. ${ }^{18}$ An early study indicated that the increase in the number of glutamate synapses is accompanied by a correlated increase in excitatory synaptic inputs, without any change in the probability of release at glutamate synapses, ${ }^{101}$ which is consistent with the ultrastructural observation of an increase in excitatory synapse number. ${ }^{96,100,108}$ However, a down-regulation of NMDA receptor subunits has also been reported with salt loading. ${ }^{109}$ A recent report described an increase in excitatory synaptic inputs that was accompanied by a robust modification of glutamate receptors by chronic salt loading, including changes in AMPA receptor subunit expression and signalling. ${ }^{18}$

Glutamate AMPA receptors are tetrameric cation channels that are usually heteromeric in nature, comprised of combinations of four AMPA receptor subunits, GluA1-GluA4, which bestow differential kinetics, voltage sensitivity and ion permeability on the receptors.
The majority of AMPA receptors in the brain contain at least one GluA2 subunit along with usually one other subunit type, often in dimer pairs. ${ }^{110}$ The GluA2 subunit prevents $\mathrm{Ca}^{2+}$ flow through the AMPA receptor channel. Therefore, unlike NMDA glutamate receptors, the majority of glutamate AMPA receptors in the brain are $\mathrm{Ca}^{2+}$ impermeable as a result of their GluA2-containing heteromeric structure.

In their recent study of AMPA receptor plasticity, Di et $\mathrm{al}^{18}$ found that mRNA expression of the four AMPA receptor subunits in the SON did not change with chronic salt loading. This was surprising given the dramatic increase in the number of glutamate synapses induced by salt loading, which one might expect to be associated with an increase in AMPA receptor expression to accommodate the new synapse formation. However, there was an increase in GluA1 subunit protein expression, by approximately $70 \%$, without a coordinate increase in the GluA2-GluA4 subunits, indicating a highly targeted post-transcriptional regulation of AMPA receptor expression by chronic osmotic stimulation. The increase in GluA1 relative to GluA2 resulted in a shift in the GluA1to-GluA2 ratio, which should increase the $\mathrm{Ca}^{2+}$ permeability of the resulting AMPA receptors as a result of the relative decrease in the $\mathrm{Ca}^{2+}$-blocking GluA2 subunit, and should therefore result in altered glutamate synaptic signalling.

\subsection{3 | $\mathrm{Ca}^{2+}$-permeable AMPA receptor induction}

Calcium-permeable AMPA receptors (ie, GluA2-lacking AMPA receptors) display a non-linear current-voltage relationship at
(A)

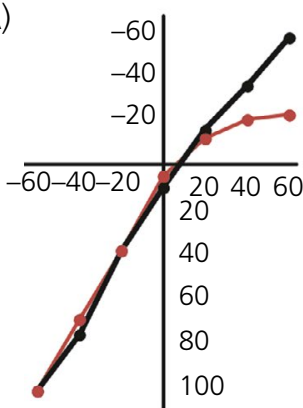

(D)

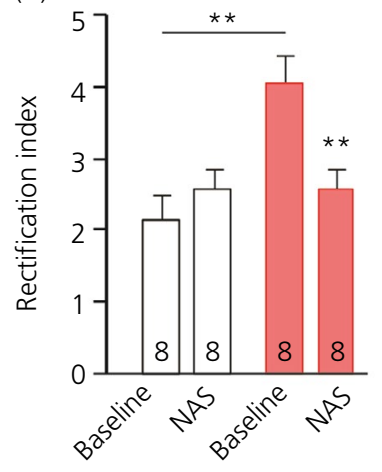

(B)

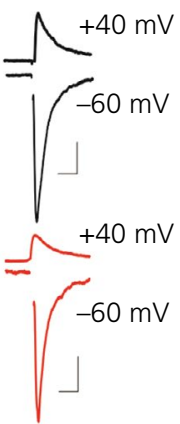

(C)

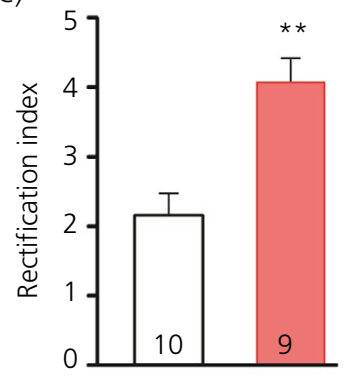

(E)

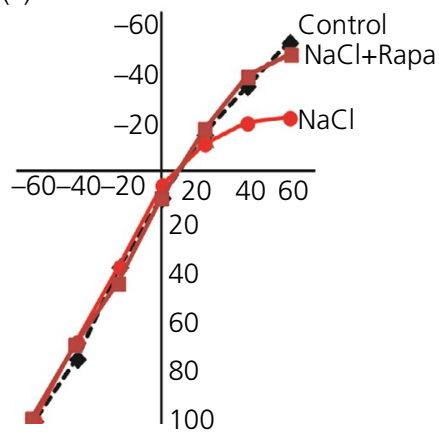

(F)

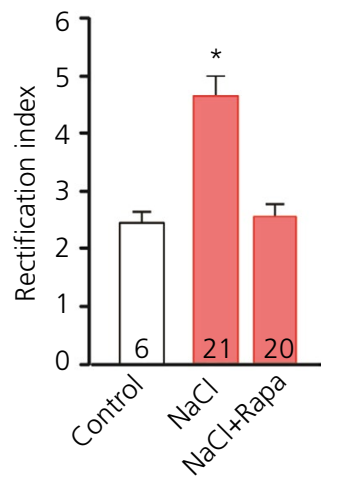

FIGURE 5 Salt loading induces new glutamate synapses composed of labile $\mathrm{Ca}^{2+}$-permeable AMPA receptors. (A-C) Salt loading increases inward rectification of AMPA currents, which is characterised by suppressed current positive to $0 \mathrm{mV}$ and a bigger - $60 \mathrm{mV}$-to- $+40 \mathrm{mV}$ current ratio (rectification index). (D-F) Antagonists of $\mathrm{Ca}^{2+}$-permeable AMPA receptors (NAS) and dendritic protein synthesis (rapamycin, Rapa) reverse the salt loading-induced change in AMPA current rectification. With permission. ${ }^{*} p<.05,{ }^{* *} p<.01$. Numbers in columns represent numbers of cells included in the means. Modified with permission from Di et $\mathrm{al}^{18}$ 
membrane potentials positive to $0 \mathrm{mV}$ as a result of the voltage-dependent binding of intracellular spermine in the pore of the GluA2lacking AMPA receptors, ${ }^{111}$ which blocks the pore of the channel and reduces its ionic conductance. In their recent report, Di et $\mathrm{al}^{18}$ also described a change in the current-voltage relationship of AMPA synaptic currents induced by salt loading. Thus, magnocellular neurones showed a linear AMPA current-voltage relationship, suggestive of GluA2-containing receptors, under control osmotic conditions, whereas the new glutamate synapses induced by salt loading generated synaptic AMPA currents in both OT and VP neurones that had highly non-linear current-voltage relations, indicative of a strong rectification caused by a lack of the GluA2 subunit (Figure 5A-C). This suggested that excitatory synapses of OT and VP neurones are composed largely of GluA2-containing AMPA receptors under control osmotic conditions, whereas new glutamate synapses formed during salt loading lack GluA2 subunits and are more permeable to $\mathrm{Ca}^{2+}$. This is in contrast to earlier studies showing that both OT and VP neurones from normally hydrated female rats exhibited AMPA current inward rectification, which was stronger in OT neurones, and AMPA-mediated $\mathrm{Ca}^{2+}$ influx in dissociated magnocellular neurones from male rats, suggesting that AMPA receptors are $\mathrm{Ca}^{2+}$ permeable as a result of a relative lack of GluA2 expression under normal conditions. ${ }^{112,113} \mathrm{Di}$ et al ${ }^{18}$ further tested this shift in AMPA receptor signalling using a GluA1specific blocker. They found that blocking GluA1 AMPA receptors had little effect on EPSCs in magnocellular neurones from control euhydrated rats but caused a significant inhibition of the EPSCs in both OT and VP neurones from salt-loaded rats (Figure 5D). It was concluded that salt loading resulted in a dramatic shift in the AMPA receptor subunit composition of excitatory synapses on the magnocellular neurones, significantly increasing the proportion of GluA1-containing, GluA2-lacking, putative calcium-permeable AMPA receptors. This suggested an induction by salt loading of homomeric GluA1 AMPA receptors that are capable of fluxing $\mathrm{Ca}^{2+}$ into the magnocellular neurones, providing a new source of $\mathrm{Ca}^{2+}$ for intracellular signalling that could contribute to the induction and/or maintenance of the synaptic and neuronal-glial plasticity observed during physiological stimulation. The $\mathrm{Ca}^{2+}$-permeable AMPA receptors could thus provide a new $\mathrm{Ca}^{2+}$ source for synaptic plasticity, or they could compensate for the putative loss of $\mathrm{Ca}^{2+}$ influx through NMDA receptors. The NMDA receptors require the co-agonist $D$-serine for activation, which is derived from astrocytes surrounding glutamate synapses. ${ }^{114}$ With the glial retraction that occurs with salt loading, like that seen during parturition, the astrocytic source of $D$-serine may be lost, which would effectively prevent the activation of NMDA receptors. ${ }^{114} \mathrm{Ca}^{2+}$-permeable AMPA receptors may compensate for this loss of NMDA receptor signalling, or may subserve new forms of synaptic plasticity.

\subsubsection{New glutamate synapses formed during salt loading are highly labile}

Interestingly, the GluA1 homomeric AMPA receptors at the glutamate synapses newly formed during salt loading require continuous protein synthesis for their maintenance. ${ }^{18}$ Preincubating brain slices in protein synthesis inhibitors silenced the new synapses with GluA2-lacking AMPA receptors, although it had little effect on the old glutamate synapses with GluA2-containing AMPA receptors. The protein synthesis at new glutamate synapses formed during salt loading was also mTOR-dependent, suggesting that the new synapses are highly labile and require continuous dendritic protein synthesis to maintain AMPA receptor function (Figure 5E,F).

Thus, as illustrated in the model in Figure 6, chronic salt loading induces new glutamate synapses on both VP and OT magnocellular neurones that appear to be composed largely of calcium-permeable
FIGURE 6 Model of AMPA receptor plasticity induced by salt loading. New glutamate synapses formed during chronic salt loading are composed of $\mathrm{Ca}^{2+}$-permeable GluA1 homomeric AMPA receptors, which are highly labile, dependent on continuous protein synthesis for their maintenance and the maintenance of the new, but not the old, glutamate synapses. The old glutamate synapses are composed of GluA2containing, $\mathrm{Ca}^{2+}$-impermeable AMPA receptors. GluA ${ }^{*}=$ GluA1, 3 , or 4

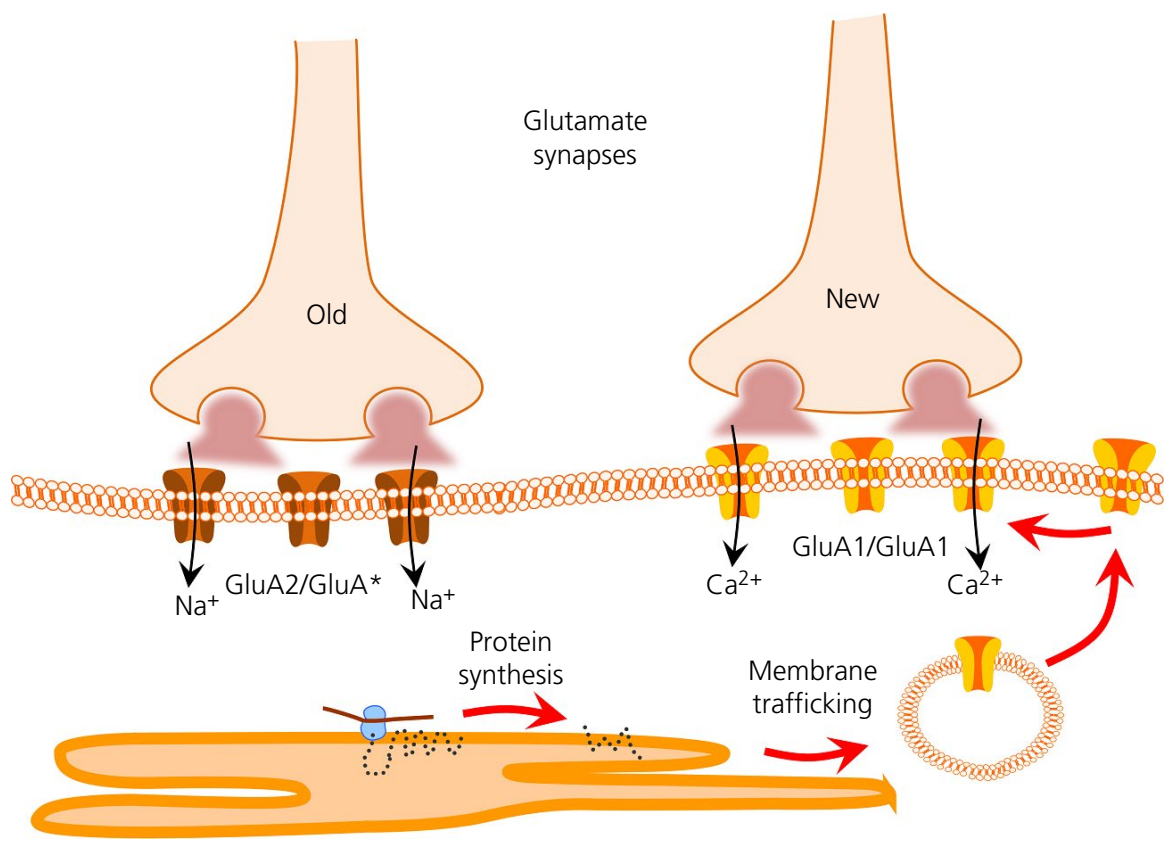


GluA1 homomeric AMPA receptors. The new synapses are labile, requiring continuous protein synthesis for the maintenance of their AMPA receptors. The lability of the synapses suggests that they are highly sensitive to osmotic conditions, undergoing functional induction and silencing based on the regulation of dendritic protein synthesis, which controls AMPA receptor trafficking into and out of the new glutamate synapses. This synaptic plasticity is therefore finely tuned to osmotic conditions, tying VP and OT neurone activation to changing osmotic conditions and thereby titrating VP and OT secretion as a function of the osmotic demands on the system.

\section{4 | Extracellular $\mathrm{Ca}^{2+}$ -} independence of neuropeptide release from
hypothalamic-neurohypophysial system terminals

Depolarisation-secretion coupling is historically assumed to be dependent on extracellular $\mathrm{Ca}^{2+}$ influx through voltage-gated $\mathrm{Ca}^{2+}$ channels (see mechanism \#1 in Figure 7) to elicit transmitter release. However, a competing theory ${ }^{115}$ invokes a distinct and separate regulation of secretion by just depolarisation (see mechanism \#4 in Figure 7).

Voltage-regulated sparks or "syntillas" of intracellular $\mathrm{Ca}^{2+}$ from ryanodine receptor-sensitive stores (see mechanism \#2 in Figure 7) have been described in axon terminals in the neurohypophysis. ${ }^{116,117}$ However, a role for $\mathrm{Ca}^{2+}$ release from intracellular $\mathrm{Ca}^{2+}$ stores, such as $\mathrm{Ca}^{2+}$-induced $\mathrm{Ca}^{2+}$ release (see mechanism \#3 in Figure 7), in secretion is controversial. Velázquez-Marrero et al ${ }^{118}$ recently showed that voltage-dependent release from intracellular ryanodine-sensitive stores provides another source of intracellular $\mathrm{Ca}^{2+}$ that contributes to neuropeptide secretion from neurohypophysial terminals.

Multiple convergent findings from the study by VelázquezMarrero et $\mathrm{al}^{118}$ point to a dependence of neuropeptide release on voltage-dependent activation of intracellular $\mathrm{Ca}^{2+}$ mobilisation. First, depolarisation-induced increases in intra-terminal $\left[\mathrm{Ca}^{2+}\right]$ and neuropeptide secretion from neurohypophysial terminals were maintained in the presence of voltage-gated $\mathrm{Ca}^{2+}$ channel blockers and in the absence of extracellular $\mathrm{Ca}^{2+}$. Capacitance measurements showing changes in membrane capacitance in $\mathrm{Ca}^{2+}$-free extracellular medium confirmed that depolarisation of the terminals elicited a significant increase in exocytosis, which was blocked by antagonist concentrations of ryanodine. Next, depolarisation of neurohypophysial terminals with high $\mathrm{K}^{+}$in a $\mathrm{Ca}^{2+}$-free extracellular medium was shown to cause an increase in neuropeptide secretion, which was blocked by ryanodine receptor antagonists. Furthermore, such depolarisations led to increases in intracellular $\left[\mathrm{Ca}^{2+}\right]$. It was then shown that depolarisation of neurohypophysial terminals with high $\mathrm{K}^{+}$following pre-incubation in the membrane-permeant $\mathrm{Ca}^{2+}$ chelator BAPTA-AM in a $\mathrm{Ca}^{2+}$-free medium resulted in a partial inhibition of the depolarisation-induced peptide secretion. A significant proportion of the response was not blocked, however, indicating that a component of the voltage-dependent neurosecretory response is

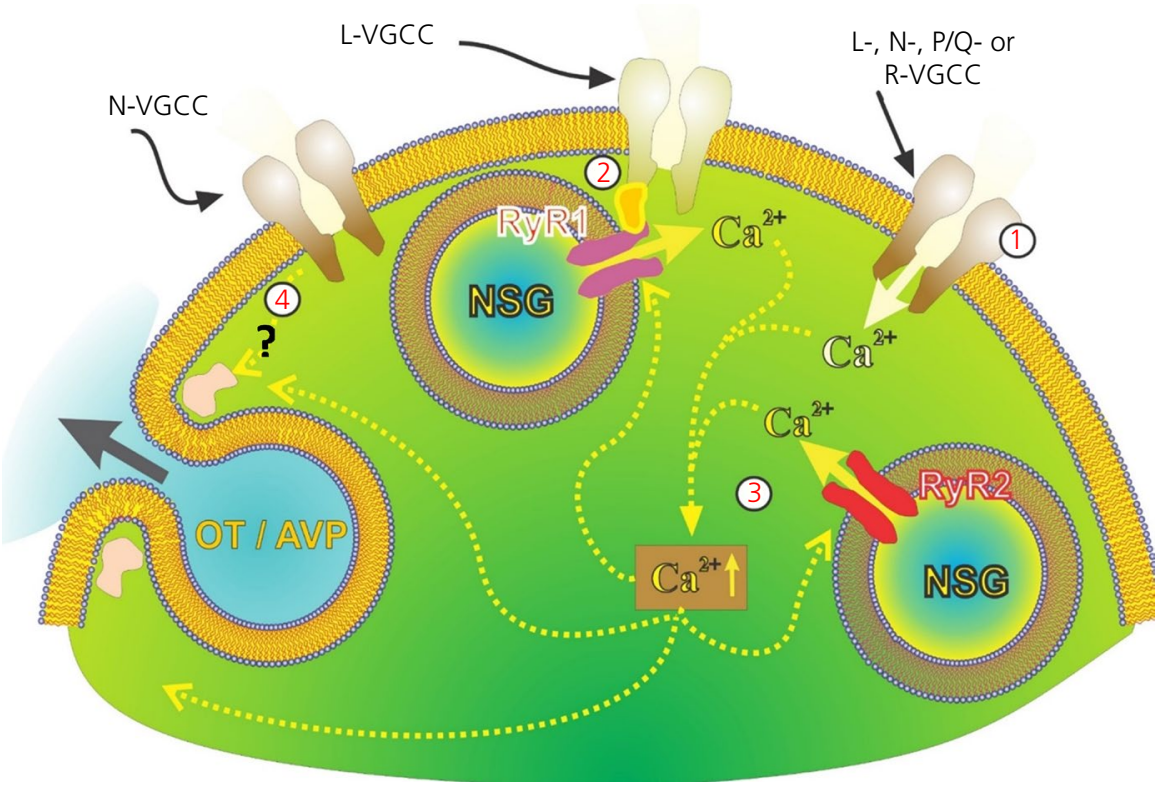

FIGURE 7 Model of different mechanisms of depolarisation-induced neuropeptide secretion from oxytocin (OT)/vasopressin (AVP) axon terminals. (1) Normally, secretion is activated by $\mathrm{Ca}^{2+}$ entry via different types of voltage-gated $\mathrm{Ca}^{2+}$ channels (VGCC). (2) Independent of extracellular $\mathrm{Ca}^{2+}$, ryanodine type-1 receptors are activated in response to depolarisation when mechanically tethered to nifedipinesensitive $\mathrm{Ca}^{2+}$ channels. Depolarisation thus allows for release of $\mathrm{Ca}^{2+}$ from ryanodine-sensitive stores contributing to the overall increase in intra-terminal $\left[\mathrm{Ca}^{2+}\right]$. (3) This and $\mathrm{Ca}^{2+}$ entry through VGCCs likely contribute to $\mathrm{Ca}^{2+}$-induced $\mathrm{Ca}^{2+}$ release from ryanodine type- 2 receptors. Intra-terminal free $\mathrm{Ca}^{2+}$ rise triggers the exocytosis releasing AVP. (4) Finally, there is secretion directly coupled to voltage and independent of both external and internal $\mathrm{Ca}^{2+}$. NSG, neurosecretory granule; RyR1 and RyR2, ryanodine receptors 1 and 2.

Drawing courtesy of Drs Cristina Velazquez and Hector Marrero (U. Puerto Rico, San Juan, PR) 
completely $\mathrm{Ca}^{2+}$-independent (see mechanism \#4 in Figure 7). The depolarisation-induced $\mathrm{Ca}^{2+}$ response and neuropeptide secretion were also tested for L-type $\mathrm{Ca}^{2+}$ channel dependence with nifedipine. Both the intra-terminal $\left[\mathrm{Ca}^{2+}\right]$ increase and neuropeptide secretion were found to be blocked, suggesting the involvement of the type-1 ryanodine receptor component of voltage-induced calcium release (see mechanism \#2 in Figure 7). ${ }^{116}$ Finally, ryanodine receptor antagonists were also shown to modulate neuropeptide release under normal physiological conditions.

Thus, as illustrated in Figure 7, there are four different mechanisms underlying neuropeptide secretion in hypothalamic-neurohypophysial nerve terminals: (i) secretion activated by $\mathrm{Ca}^{2+}$ entry via voltage-gated $\mathrm{Ca}^{2+}$ channels; (ii) secretion activated by $\mathrm{Ca}^{2+}$ released from intracellular stores via $\mathrm{Ca}^{2+}$-induced $\mathrm{Ca}^{2+}$ release; (iii) secretion triggered by $\mathrm{Ca}^{2+}$ release from intracellular stores activated directly by voltage (ie, analogous to that observed in skeletal muscle); and (iv) secretion directly coupled to voltage and independent of $\mathrm{Ca}^{2+}$ (ie, analogous to that observed in DRG somata ${ }^{119}$ ).

It appears that approximately $60 \%$ of the neuropeptide secretion depends on external $\mathrm{Ca}^{2+}$ (see mechanism \#1 in Figure 7) and the reduction in secretion produced by nifedipine or ryanodine in $0 \mathrm{Ca}^{2+}$ corresponds to approximately $20 \%$ of the total secretion in normal external $\mathrm{Ca}^{2+}$ (see mechanism \#2 and mechanism \#3 in Figure 7). The remaining approximately $20 \%$ of secretion appears to be $\mathrm{Ca}^{2+}$-independent, but voltage-dependent (see mechanism \#4 in Figure 7). This last component lends support to the competing theory of Parnas \& Parnas ${ }^{115}$ with respect to $\mathrm{Ca}^{2+}$-independent secretion at nerve terminals.

Extracellular $\mathrm{Ca}^{2+}$-independent secretion could explain the efficacy of neuropeptide secretion at the end of a burst in situ, when increases in extracellular $\left[\mathrm{K}^{+}\right]$should depolarise the terminals and extracellular $\left[\mathrm{Ca}^{2+}\right]$ should be decreased within the neurohypophysial interstitial spaces, reducing $\mathrm{Ca}^{2+}$ influx. ${ }^{120-122}$ Importantly, under normal conditions, high $\left[\mathrm{K}^{+}\right]$in the interstitial spaces should increase the number of syntillas in the terminals, and this would increase intracellular $\left[\mathrm{Ca}^{2+}\right]$, leading to facilitation of release and compensating for the decrease in extracellular $\left[\mathrm{Ca}^{2+}\right]$. Furthermore, during physiological stress, such as salt loading, when morphological plasticity decreases the interstitial space around terminals, ${ }^{123} \mathrm{Ca}^{2+}$-induced $\mathrm{Ca}^{2+}$ release from intracellular stores would increase because larger changes in both extracellular $\mathrm{Ca}^{2+}$ and $\mathrm{K}^{+}$would make compensation in release more necessary. Therefore, during salt loading, there would be more depolarisation-induced $\mathrm{Ca}^{2+}$ sparks to meet this increased demand for peptide release.

Thus, these recent findings ${ }^{118}$ demonstrate that both voltage-dependent $\mathrm{Ca}^{2+}$ release from ryanodine receptor-mediated intracellular stores and extracellular $\mathrm{Ca}^{2+}$-independent, voltage-dependent mechanisms contribute to the secretion of neuropeptides from magnocellular neurone terminals in the neurohypophysis. This does not occur at the soma/dendrites of the magnocellular neurones in the hypothalamus, where receptor-mediated intracellular $\mathrm{Ca}^{2+}$ release is mediated by inositol trisphosphate receptors. ${ }^{124}$ This constitutes an important difference in the secretion mechanisms between the magnocellular cell bodies and their terminals. ${ }^{125}$ It remains to be seen whether ryanodine receptor-mediated $\mathrm{Ca}^{2+}$ release recruits neurosecretory granules at terminals to facilitate secretion, as occurs at dendrites. ${ }^{126}$ These mechanisms should have widespread importance because bursting patterns of action potentials are necessary for the secretion of not only these neuropeptides, but also many other neurotransmitters in the central and peripheral nervous systems.

\section{2 | CONCLUSIONS}

We have briefly highlighted recent studies focusing on the neurophysiology of OT and VP neurones that were presented at the 2019 World Congress on Neurohypophysial Hormones. These studies are just a sampling of the neurophysiological investigation occurring in the hypothalamic-neurohypophysial system, presented to provide a snapshot of some of the unique physiological properties and the remarkable structural and functional plasticity of this benchmark neuroendocrine system. It is clear from such work that the OT/VP neurones continue to provide a tractable model system for gaining new insights into neurophysiological mechanisms that contribute to our general understanding of neuronal and hormonal signalling. We look forward to exciting new discoveries in OT and VP neurone cellular and network neurophysiology in the years to come.

\section{ACKNOWLEDGEMENTS}

This work was supported by Canadian Institutes of Health Research grant PJT-153009 and a Heart \& Stroke Foundation of Canada National New Investigator Award to MPK; and by US National Institutes of Health grants R01HL115208 and R21HL093728 to RT, P20GM103642 and R01NS29470 to JRL, R01NS042081 to JGT, and R01HD072056 to WEA.

\section{ORCID}

Jeffrey G. Tasker ID https://orcid.org/0000-0003-1977-4199

Masha Prager-Khoutorsky iD https://orcid.

org/0000-0001-5388-4602

José R. Lemos (iD https://orcid.org/0000-0002-9234-0680

William E. Amstrong (iD https://orcid.org/0000-0003-2280-4969

\section{REFERENCES}

1. Poulain DA, Wakerley JB. Electrophysiology of hypothalamic magnocellular neurones secreting oxytocin and vasopressin. Neuroscience. 1982;7:773-808.

2. Mason WT. Supraoptic neurones of rat hypothalamus are osmosensitive. Nature. 1980;287:154-157.

3. Abe $\mathrm{H}$, Ogata $\mathrm{N}$. Ionic mechanism for the osmotically-induced depolarization in neurones of the guinea-pig supraoptic nucleus in vitro. J Physiol. 1982;327:157-171.

4. Bourque CW, Renaud LP. Activity patterns and osmosensitivity of rat supraoptic neurones in perfused hypothalamic explants. J Physiol. 1984;349:631-642.

5. Bansal V, Fisher TE. Osmotic activation of a $\mathrm{Ca}(2+)$-dependent phospholipase $\mathrm{C}$ pathway that regulates N TRPV1-mediated currents in rat supraoptic neurons. Physiol Rep. 2017;5:e13259. 
6. Sharif-Naeini R, Witty MF, Seguela P, Bourque CW. An N-terminal variant of Trpv1 channel is required for osmosensory transduction. NatNeurosci. 2006;9:93-98.

7. Zaelzer C, Hua P, Prager-Khoutorsky M, et al. DeltaN-TRPV1: A Molecular Co-detector of Body Temperature and Osmotic Stress. Cell Rep. 2015;13:23-30.

8. Miyata S. Advances in Understanding of Structural Reorganization in the Hypothalamic Neurosecretory System. Front Endocrinol (Lausanne). 2017;8:8275.

9. Choe KY, Trudel E, Bourque CW. Effects of salt loading on the regulation of rat hypothalamic magnocellular neurosecretory cells by ionotropic gaba and glycine receptors. J Neuroendocrinol. 2016;28:10.1111/jne.12372.

10. Hatton $\mathrm{Gl}$. Dynamic neuronal-glial interactions: an overview 20 years later. Peptides. 2004;25:403-411.

11. Theodosis DT. Oxytocin-secreting neurons: A physiological model of morphological neuronal and glial plasticity in the adult hypothalamus. Front Neuroendocrinol. 2002;23:101-135.

12. Armstrong WE, Wang L, Li C, Teruyama R. Performance, properties and plasticity of identified oxytocin and vasopressin neurones in vitro. J Neuroendocrinol. 2010;22:330-342.

13. Tasker JG, Oliet SH, Bains JS, Brown CH, Stern JE. Glial regulation of neuronal function: from synapse to systems physiology. J Neuroendocrinol. 2012;24:566-576.

14. Theodosis DT, Poulain DA, Oliet SH. Activity-dependent structural and functional plasticity of astrocyte-neuron interactions. Physiol Rev. 2008;88:983-1008.

15. Stern JE, Hestrin S, Armstrong WE. Enhanced neurotransmitter release at glutamatergic synapses on oxytocin neurones during lactation in the rat. J Physiol. 2000;526:109-114.

16. Oliet SH. Functional consequences of morphological neuroglial changes in the magnocellular nuclei of the hypothalamus. J Neuroendocrinol. 2002;14:241-246.

17. Brussaard $A B$, Herbison $A E$. Long-term plasticity of postsynaptic GABAA-receptor function in the adult brain: insights from the oxytocin neurone. Trends Neurosci. 2000;23:190-195.

18. Di S, Jiang Z, Wang S, et al. Labile calcium-permeable AMPA receptors constitute new glutamate synapses formed in hypothalamic neuroendocrine cells during salt loading. eNeuro. 2019;6:EN EURO.0112-19.2019.

19. Wang L, Chandaka GK, Foehring RC, Callaway JC, Armstrong WE. Changes in potassium channel modulation may underlie afterhyperpolarization plasticity in oxytocin neurons during late pregnancy. J Neurophysiol. 2018;119:1745-1752.

20. Stern JE, Armstrong WE. Changes in the electrical properties of supraoptic nucleus oxytocin and vasopressin neurons during lactation. J Neurosci. 1996;16:4861-4871.

21. Teruyama R, Armstrong WE. Enhancement of calcium-dependent afterpotentials in oxytocin neurons of the rat supraoptic nucleus during lactation. J Physiol. 2005;566:505-518.

22. Zhang W, Star B, Rajapaksha WR, Fisher TE. Dehydration increases L-type $\mathrm{Ca}(2+)$ current in rat supraoptic neurons. J Physiol. 2007;580:181-193.

23. Balapattabi K, Farmer GE, Knapp BA, et al. Effects of salt-loading on supraoptic vasopressin neurones assessed by ClopHensorN chloride imaging. J Neuroendocrinol. 2019;31:e12752.

24. Kim YB, Kim YS, Kim WB, et al. GABAergic excitation of vasopressin neurons: possible mechanism underlying sodium-dependent hypertension. Circ Res. 2013;113:1296-1307.

25. Bourque CW. Activity-dependent modulation of nerve terminal excitation in a mammalian peptidergic system. Trends Neurosci. 1991;14:28-30.

26. Fisher TE, Bourque CW. Calcium-channel subtypes in the somata and axon terminals of magnocellular neurosecretory cells. Trends Neurosci. 1996;19:440-444.
27. Jackson MB, Konnerth A, Augustine GJ. Action potential broadening and frequency-dependent facilitation of calcium signals in pituitary nerve terminals. Proc Natl Acad Sci USA. 1991;88:380-384.

28. Lemos JR, Nowycky MC. Two types of calcium channels coexist in peptide-releasing vertebrate nerve terminals. Neuron. 1989;2:1419-1426.

29. McMahon SM, Chang CW, Jackson MB. Multiple cytosolic calcium buffers in posterior pituitary nerve terminals. J Gen Physiol. 2016;147:243-254.

30. Oliet SH, Bourque CW. Properties of supraoptic magnocellular neurones isolated from the adult rat. J Physiol. 1992;455:291-306.

31. Sharif-Naeini R, Ciura S, Stachniak TJ, Trudel E, Bourque CW. Neurophysiology of supraoptic neurons in C57/BL mice studied in three acute in vitro preparations. Prog Brain Res. 2008;170:229-242.

32. Bourque CW. Central mechanisms of osmosensation and systemic osmoregulation. Nat Rev Neurosci. 2008;9:519-531.

33. Zhang Z, Bourque CW. Osmometry in osmosensory neurons. Nat Neurosci. 2003;6:1021-1022.

34. Zhang Z, Kindrat AN, Sharif-Naeini R, Bourque CW. Actin filaments mediate mechanical gating during osmosensory transduction in rat supraoptic nucleus neurons. J Neurosci. 2007;27:4008-4013.

35. Prager-Khoutorsky M, Bourque CW. Mechanical basis of osmosensory transduction in magnocellular neurosecretory neurones of the rat supraoptic nucleus. J Neuroendocrinol. 2015;27:507-515.

36. Strange K. Cellular volume homeostasis. Adv Physiol Educ. 2004;28:155-159.

37. Lang F. Mechanisms and significance of cell volume regulation. J Am Coll Nutr. 2007;26(5 Suppl):613S-S623.

38. Oliet SH, Bourque CW. Mechanosensitive channels transduce osmosensitivity in supraoptic neurons. Nature. 1993;364:341-343.

39. Prager-Khoutorsky M, Bourque CW. Osmosensation in vasopressin neurons: changing actin density to optimize function. Trends Neurosci. 2010;33:76-83.

40. Zhang Z, Bourque CW. Amplification of transducer gain by angiotensin II-mediated enhancement of cortical actin density in osmosensory neurons. J Neurosci. 2008;28:9536-9544.

41. Prager-Khoutorsky M. Mechanosensing in hypothalamic osmosensory neurons. Semin Cell Dev Biol. 2017;71:13-21.

42. Goswami C, Dreger M, Jahnel R, Bogen O, Gillen C, Hucho F. Identification and characterization of a $\mathrm{Ca}^{2+}$-sensitive interaction of the vanilloid receptor TRPV1 with tubulin. J Neurochem. 2004;91:1092-1103.

43. Goswami C, Hucho T. Submembraneous microtubule cytoskeleton: biochemical and functional interplay of TRP channels with the cytoskeleton. FEBS J. 2008;275:4684-4699.

44. Prager-Khoutorsky M, Khoutorsky A, Bourque CW. Unique interweaved microtubule scaffold mediates osmosensory transduction via physical interaction with TRPV1. Neuron. 2014;83:866-878.

45. Stiess M, Bradke F. Neuronal polarization: the cytoskeleton leads the way. Dev Neurobiol. 2011;71:430-444.

46. Hicks Al, Barad Z, Sobrero A, et al. Effects of salt loading on the organization of microtubules in rat magnocellular vasopressin neurons. J Neuroendocrinol. 2019;31:e12817.

47. Luxton GW, Gundersen GG. Orientation and function of the nuclear-centrosomal axis during cell migration. Curr Opin Cell Biol. 2011;23:579-588.

48. Goswami C, Hucho TB, Hucho F. Identification and characterisation of novel tubulin-binding motifs located within the $\mathrm{C}$-terminus of TRPV1. J Neurochem. 2007;101:250-262.

49. Berdiev BK, Karlson KH, Jovov B, et al. Subunit stoichiometry of a core conduction element in a cloned epithelial amiloride-sensitive $\mathrm{Na}+$ channel. Biophys J. 1998;75:2292-2301.

50. Firsov D, Gautschi I, Merillat AM, Rossier BC, Schild L. The heterotetrameric architecture of the epithelial sodium channel $(\mathrm{ENaC})$. EMBO J. 1998;17:344-352. 
51. Snyder PM, Cheng C, Prince LS, Rogers JC, Welsh MJ. Electrophysiological and biochemical evidence that DEG/ENaC cation channels are composed of nine subunits. J Biol Chem. 1998;273:681-684.

52. Kosari F, Sheng S, Li J, Mak DO, Foskett JK, Kleyman TR. Subunit stoichiometry of the epithelial sodium channel. J Biol Chem. 1998;273:13469-13474.

53. Eskandari S, Snyder PM, Kreman M, Zampighi GA, Welsh MJ, Wright EM. Number of subunits comprising the epithelial sodium channel. J Biol Chem. 1999;274:27281-27286.

54. Staruschenko A, Medina JL, Patel P, Shapiro MS, Booth RE, Stockand JD. Fluorescence resonance energy transfer analysis of subunit stoichiometry of the epithelial $\mathrm{Na}+$ channel. J Biol Chem. 2004;279:27729-27734.

55. Staruschenko A, Adams E, Booth RE, Stockand JD. Epithelial Na+ channel subunit stoichiometry. Biophys J. 2005;88:3966-3975.

56. Canessa CM, Schild L, Buell G, et al. Amiloride-sensitive epithelial $\mathrm{Na}+$ channel is made of three homologous subunits. Nature. 1994;367:463-467.

57. Benos DJ, Awayda MS, Ismailov II, Johnson JP. Structure and function of amiloride-sensitive $\mathrm{Na}^{+}$channels. J Membr Biol. 1995:143:1-18.

58. Garty H, Palmer LG. Epithelial sodium channels: function, structure, and regulation. Physiol Rev. 1997;77:359-396.

59. Shimkets RA, Warnock DG, Bositis CM, et al. Liddle's syndrome: heritable human hypertension caused by mutations in the beta subunit of the epithelial sodium channel. Cell. 1994;79:407-414.

60. Mune T, Rogerson FM, Nikkila H, Agarwal AK, White PC. Human hypertension caused by mutations in the kidney isozyme of 11 beta-hydroxysteroid dehydrogenase. Nat Genet. 1995;10:394-399.

61. Lifton RP. Molecular genetics of human blood pressure variation. Science. 1996;272:676-680.

62. Dahlberg J, Nilsson LO, von Wowern F, Melander O. Polymorphism in NEDD4L is associated with increased salt sensitivity, reduced levels of P-renin and increased levels of Nt-proANP. PLoS ONE. 2007;2:e432.

63. Zhou R, Patel SV, Snyder PM. Nedd4-2 catalyzes ubiquitination and degradation of cell surface ENaC. J Biol Chem. 2007;282:20207-20212.

64. Gomez-Sanchez EP, Gomez-Sanchez CE. Effect of central amiloride infusion on mineralocorticoid hypertension. Am J Physiol. 1994;267:E754-E758.

65. Wang $\mathrm{H}$, Leenen $\mathrm{FH}$. Brain sodium channels mediate increases in brain "ouabain" and blood pressure in Dahl S rats. Hypertension. 2002;40:96-100.

66. Gomez-Sanchez EP, Gomez-Sanchez CE. Effect of central infusion of benzamil on Dahl S rat hypertension. Am J Physiol. 1995;269:H1044-H1047.

67. Osborn JW, Olson DM, Guzman P, Toney GM, Fink GD. The neurogenic phase of angiotensin II-salt hypertension is prevented by chronic intracerebroventricular administration of benzamil. Physiol Rep. 2014;2:e00245.

68. Lu J, Wang HW, Ahmad M, et al. Central and peripheral slow-pressor mechanisms contributing to Angiotensin II-salt hypertension in rats. Cardiovasc Res. 2018;114:233-246.

69. Huang BS, White RA, Ahmad M, Leenen FH. Role of brain corticosterone and aldosterone in central angiotensin II-induced hypertension. Hypertension. 2013;62:564-571.

70. Gabor A, Leenen FH. Central mineralocorticoid receptors and the role of angiotensin II and glutamate in the paraventricular nucleus of rats with angiotensin II-induced hypertension. Hypertension. 2013;61:1083-1090.

71. Chen A, Huang BS, Wang HW, Ahmad M, Leenen FH. Knockdown of mineralocorticoid or angiotensin II type 1 receptor gene expression in the paraventricular nucleus prevents angiotensin II hypertension in rats. J Physiol. 2014;592:3523-3536.

72. Chen J, Gomez-Sanchez CE, Penman A, May PJ, Gomez-Sanchez E. Expression of mineralocorticoid and glucocorticoid receptors in preautonomic neurons of the rat paraventricular nucleus. Am J Physiol Regul Integr Comp Physiol. 2014;306:R328-R340.

73. Amin MS, Reza E, Wang H, Leenen FH. Sodium transport in the choroid plexus and salt-sensitive hypertension. Hypertension. 2009;54:860-867.

74. Nakano M, Hirooka $\mathrm{Y}$, Matsukawa $\mathrm{R}$, Ito $\mathrm{K}$, Sunagawa $\mathrm{K}$. Mineralocorticoid receptors/epithelial $\mathrm{Na}(+)$ channels in the choroid plexus are involved in hypertensive mechanisms in stroke-prone spontaneously hypertensive rats. Hypertens Res. 2013;36:277-284.

75. Amin MS, Wang HW, Reza E, Whitman SC, Tuana BS, Leenen FH. Distribution of epithelial sodium channels and mineralocorticoid receptors in cardiovascular regulatory centers in rat brain. Am J Physiol Regul Integr Comp Physiol. 2005;289:R1787-R1797.

76. Teruyama R, Sakuraba M, Wilson LL, Wandrey NE, Armstrong WE. Epithelial $\mathrm{Na}(+)$ sodium channels in magnocellular cells of the rat supraoptic and paraventricular nuclei. Am J Physiol Endocrinol Metab. 2012;302:E273-E285.

77. Han J, Gnatenco C, Sladek CD, Kim D. Background and tandem-pore potassium channels in magnocellular neurosecretory cells of the rat supraoptic nucleus. J Physiol. 2003;546:625-639.

78. Teruyama R, Armstrong WE. Changes in the active membrane properties of rat supraoptic neurones during pregnancy and lactation. J Neuroendocrinol. 2002;14:933-944.

79. Bourque $\mathrm{CW}$. Transient calcium-dependent potassium current in magnocellular neurosecretory cells of the rat supraoptic nucleus. J Physiol. 1988;397:331-347.

80. Bicknell RJ. Optimizing release from peptide hormone secretory nerve terminals. J Exp Biol. 1988;139:51-65.

81. Cazalis M, Dayanithi G, Nordmann JJ. The role of patterned burst and interburst interval on the excitation- coupling mechanism in the isolated rat neural lobe. J Physiol. 1985;369:45-60.

82. Brown $\mathrm{CH}$, Bourque $\mathrm{CW}$. Mechanisms of rhythmogenesis: insights from hypothalamic vasopressin neurons. Trends Neurosci. 2006;29:108-115.

83. Li C, Tripathi PK, Armstrong WE. Differences in spike train variability in rat vasopressin and oxytocin neurons and their relationship to synaptic activity. J Physiol. 2007;581:221-240.

84. Sharma K, Haque M, Guidry R, Ueta Y, Teruyama R. Effect of dietary salt intake on epithelial $\mathrm{Na}+$ channels $(\mathrm{ENaC})$ in vasopressin magnocellular neurosecretory neurons in the rat supraoptic nucleus. J Physiol. 2017;595:5857-5874.

85. Teruyama R, Armstrong WE. Calcium-dependent fast depolarizing afterpotentials in vasopressin neurons in the rat supraoptic nucleus. J Neurophysiol. 2007;98:2612-2621.

86. Masilamani S, Kim GH, Mitchell C, Wade JB, Knepper MA. Aldosterone-mediated regulation of $\mathrm{ENaC}$ alpha, beta, and gamma subunit proteins in rat kidney. J Clin Invest. 1999;104:R19-23.

87. Masilamani $\mathrm{S}$, Wang $\mathrm{X}$, Kim GH, et al. Time course of renal $\mathrm{Na}-\mathrm{K}$ ATPase, NHE3, NKCC2, NCC, and ENaC abundance changes with dietary NaCl restriction. Am J Physiol Renal Physiol. 2002;283:F648-F657.

88. Crestani S, Gasparotto Junior A, Marques MC, Sullivan JC, Webb RC, da Silva-Santos JE. Enhanced angiotensin-converting enzyme activity and systemic reactivity to angiotensin II in normotensive rats exposed to a high-sodium diet. Vascul Pharmacol. 2014;60:67-74.

89. Kamari Y, Shimoni N, Koren F, Peleg E, Sharabi Y, Grossman E. High-salt diet increases plasma adiponectin levels independent of blood pressure in hypertensive rats: the role of the renin-angiotensin-aldosterone system. J Hypertens. 2010;28:95-101.

90. Mills NJ, Sharma K, Haque M, Moore M, Teruyama R. Aldosterone mediated regulation of epithelial sodium channel $(\mathrm{ENaC})$ subunits in the rat hypothalamus. Neuroscience. 2018;390:278-292. 
91. Gomez-Sanchez EP, Ahmad N, Romero DG, Gomez-Sanchez CE. Is aldosterone synthesized within the rat brain? Am J Physiol Endocrinol Metab. 2005;288:E342-E346.

92. MacKenzie SM, Clark CJ, Fraser R, Gomez-Sanchez CE, Connell JM, Davies E. Expression of 11beta-hydroxylase and aldosterone synthase genes in the rat brain. J Mol Endocrinol. 2000;24:321-328.

93. Wang HW, Huang BS, Chen A, Ahmad M, White RA, Leenen FH. Role of brain aldosterone and mineralocorticoid receptors in aldosterone-salt hypertension in rats. Neuroscience. 2016;314:90-105.

94. Inenaga K, Nagatomo T, Kannan H, Yamashita H. Inward sodium current involvement in regenerative bursting activity of rat magnocellular supraoptic neurones in vitro. J Physiol. 1993;465:289-301.

95. Tasker JG, Voisin DL, Armstrong WE. The cell biology of oxytocin and vasopressin cells. In: Pfaff D, Joels M, eds. Hormones, Brain and Behavior. Vol 3. Cambridge, MA: Academic Press; 2017:305-336.

96. El Majdoubi M, Poulain DA, Theodosis DT. Activity-dependent morphological synaptic plasticity in an adult neurosecretory system: magnocellular oxytocin neurons of the hypothalamus. Biochem Cell Biol. 2000;78:317-327.

97. Hatton GI. Function-related plasticity in hypothalamus. Annu Rev Neurosci. 1997;20:375-397.

98. Theodosis DT, Trailin A, Poulain DA. Remodeling of astrocytes, a prerequisite for synapse turnover in the adult brain? Insights from the oxytocin system of the hypothalamus. Am J Physiol Regul Integr Comp Physiol. 2006;290:R1175-R1182.

99. Choe KY, Han SY, Gaub P, et al. High salt intake increases blood pressure via BDNF-mediated downregulation of $\mathrm{KCC} 2$ and impaired baroreflex inhibition of vasopressin neurons. Neuron. 2015;85:549-560.

100. Miyata S, Nakashima T, Kiyohara T. Structural dynamics of neural plasticity in the supraoptic nucleus of the rat hypothalamus during dehydration and rehydration. Brain Res Bull. 1994;34:169-175.

101. Di S, Tasker JG. Dehydration-induced synaptic plasticity in magnocellular neurons of the hypothalamic supraoptic nucleus. Endocrinology. 2004;145:5141-5149.

102. Kim JS, Kim WB, Kim YB, et al. Chronic hyperosmotic stress converts GABAergic inhibition into excitation in vasopressin and oxytocin neurons in the rat. J Neurosci. 2011;31:13312-13322.

103. Konopacka A, Qiu J, Yao ST, et al. Osmoregulation requires brain expression of the renal $\mathrm{Na}-\mathrm{K}-2 \mathrm{Cl}$ cotransporter NKCC2. J Neurosci. 2015;35:5144-5155.

104. Lee SW, Kim YB, Kim JS, et al. GABAergic inhibition is weakened or converted into excitation in the oxytocin and vasopressin neurons of the lactating rat. Mol Brain. 2015;8:34.

105. Morton LA, Popescu IR, Haam J, Tasker JG. Short-term potentiation of GABAergic synaptic inputs to vasopressin and oxytocin neurones. J Physiol. 2014;592:4221-4233.

106. Haam J, Halmos KC, Di S, Tasker JG. Nutritional state-dependent ghrelin activation of vasopressin neurons via retrograde trans-neuronal-glial stimulation of excitatory GABA circuits. J Neurosci. 2014;34:6201-6213.

107. Kim YB, Kim WB, Jung WW, et al. Excitatory GABAergic action and increased vasopressin synthesis in hypothalamic magnocellular neurosecretory cells underlie the high plasma level of vasopressin in diabetic rats. Diabetes. 2018;67:486-495.

108. Perlmutter LS, Tweedle CD, Hatton GI. Neuronal/glial plasticity in the supraoptic dendritic zone in response to acute and chronic dehydration. Brain Res. 1985;361:225-232.

109. Curras-Collazo MC, Dao J. Osmotic activation of the hypothalamo-neurohypophysial system reversibly downregulates the NMDA receptor subunit, NR2B, in the supraoptic nucleus of the hypothalamus. Brain Res Mol Brain Res. 1999;70:187-196.

110. Cull-Candy S, Kelly L, Farrant M. Regulation of $\mathrm{Ca}^{2+}$-permeable AMPA receptors: synaptic plasticity and beyond. Curr Opin Neurobiol. 2006;16:288-297.
111. Bowie D. Polyamine-mediated channel block of ionotropic glutamate receptors and its regulation by auxiliary proteins. J Biol Chem. 2018;293:18789-18802.

112. Petralia RS, Wenthold RJ. Light and electron immunocytochemical localization of AMPA-selective glutamate receptors in the rat brain. J Comp Neurol. 1992;318:329-354.

113. Stern JE, Galarreta M, Foehring RC, Hestrin S, Armstrong WE. Differences in the properties of ionotropic glutamate synaptic currents in oxytocin and vasopressin neuroendocrine neurons. J Neurosci. 1999;19:3367-3375.

114. Panatier A, Theodosis DT, Mothet JP, et al. Glia-derived D-serine controls NMDA receptor activity and synaptic memory. Cell. 2006;125:775-784.

115. Parnas I, Parnas H. Calcium is essential but insufficient for neurotransmitter release: the calcium-voltage hypothesis. J Physiol (Paris). 1986;81:289-305.

116. De Crescenzo V, Fogarty KE, Zhuge R, et al. Dihydropyridine receptors and type 1 ryanodine receptors constitute the molecular machinery for voltage-induced $\mathrm{Ca}^{2+}$ release in nerve terminals. J Neurosci. 2006;26:7565-7574.

117. De Crescenzo V, ZhuGe R, Velazquez-Marrero C, et al. $\mathrm{Ca}^{2+}$ syntillas, miniature $\mathrm{Ca}^{2+}$ release events in terminals of hypothalamic neurons, are increased in frequency by depolarization in the absence of $\mathrm{Ca}^{2+}$ influx. J Neurosci. 2004;24:1226-1235.

118. Velázquez-Marrero $\mathrm{C}$, Custer EE, Marrero H, Ortiz-Miranda S, Lemos JR. Voltage-mediated calcium dependence of neuropeptide release from magnocellular neuronal terminals. J Neuroendocrinol. 2020. (In press).

119. Zhang C, Zhou Z. Ca(2+)-independent but voltage-dependent secretion in mammalian dorsal root ganglion neurons. Nat Neurosci. 2002;5:425-430

120. Marrero HG, Lemos JR. Frequency-dependent potentiation of voltage-activated responses only in the intact neurohypophysis of the rat. Pflugers Arch. 2005;450:96-110.

121. Leng G, Shibuki K. Extracellular potassium changes in the rat neurohypophysis during activation of the magnocellular neurosecretory system. J Physiol. 1987;392:97-111.

122. Leng G, Shibuki K, Way SA. Effects of raised extracellular potassium on the excitability of, and hormone release from, the isolated rat neurohypophysis. J Physiol. 1988;399:591-605.

123. Perlmutter LS, Tweedle CD, Hatton GI. Neuronal/glial plasticity in the supraoptic dendritic zone: dendritic bundling and double synapse formation at parturition. Neuroscience. 1984;13:769-779.

124. Hamada T, Liou SY, Fukushima T, et al. The role of inositol trisphosphate-induced $\mathrm{Ca}^{2+}$ release from IP3-receptor in the rat suprachiasmatic nucleus on circadian entrainment mechanism. Neurosci Lett. 1999:263:125-128.

125. Dayanithi G, Lemos JR. Hypothalamic Somata vs. Neurohypophysial Terminals. In: Lemos JR, Dayanithi G, eds. Neurosecretion: Secretory Mechanisms: Springer Nature 2020: in press. Cham, Switzerland: Springer Nature.

126. Ludwig M, Sabatier N, Bull PM, Landgraf R, Dayanithi G, Leng G Intracellular calcium stores regulate activity-dependent neuropeptide release from dendrites. Nature. 2002;418:85-89.

How to cite this article: Tasker JG, Prager-Khoutorsky M, Teruyama R, Lemos JR, Amstrong WE. Advances in the neurophysiology of magnocellular neuroendocrine cells. J Neuroendocrinol. 2020;32:e12826. https://doi.org/10.1111/ jne.12826 